\title{
Influence of Humidity and Temperature on Postharvest Needle Abscission in Balsam Fir in the Presence and Absence of Exogenous Ethylene
}

\author{
Mason T. MacDonald and Rajasekaran R. Lada ${ }^{1}$ \\ Christmas Tree Research Center, Nova Scotia Agricultural College, P.O. \\ Box 550, Bible Hill, NS, B2N 5E3, Canada
}

\section{Martine Dorais and Steeve Pepin \\ Center for Horticultural Research, Université Laval, Quebec City, Quebec, G1V 0A6, Canada}

Additional index words. Abies balsamea, Christmas tree, conifer, evergreen, senescence, vapor pressure deficit

\begin{abstract}
Ethylene accumulation increases after harvest and culminates in needle abscission in balsam fir [Abies balsamea (L.) Mill.]. We hypothesize that water deficit induces ethylene evolution, thus triggering abscission. The purpose of this research was to investigate the role of temperature and humidity on postharvest needle abscission in the presence and absence of exogenous ethylene and link vapor pressure deficit (VPD) to postharvest needle abscission in balsam fir. In the first experiment, branches were exposed to $30 \%, 60 \%$, or $90 \%$ humidity while maintained at $19.7^{\circ} \mathrm{C}$ (VPD of $1.59,0.91$, or $0.23 \mathrm{kPa}$, respectively); in the second experiment, branches were exposed to 5,15 , or $25^{\circ} \mathrm{C}$ (VPD of $0.35,0.68$, or $1.26 \mathrm{kPa}$, respectively) while maintained at $60 \%$ relative humidity. Needle retention duration, average water use, xylem pressure potential relative water content, and ethylene evolution were response variables. Reducing water loss or xylem tension by changing temperature or humidity effectively delayed needle abscission, although the $\mathbf{9 0 \%}$ humidity treatment had the most profound effects. In the absence of exogenous ethylene, branches placed in $90 \%$ humidity had a fivefold increase in needle retention, $67 \%$ decrease in average water use, and had a final xylem pressure potential of $-0.09 \mathrm{MPa}$. There was a near perfect relationship between VPD and needle retention $\left(R^{2}=0.99\right)$. These findings suggest that increasing xylem tension or decreasing water status may trigger ethylene synthesis and needle abscission. In addition, these findings demonstrate an effective means of controlling postharvest needle abscission by modifying temperature and/or relative humidity.
\end{abstract}

Balsam fir is an important horticultural crop for provinces in Atlantic Canada, including Nova Scotia, New Brunswick, Prince Edward Island, and Newfoundland. Each year the region supplies over 3 million trees for local and international use as Christmas trees (MacDonald, 2010). However, a major challenge for the Christmas tree industry is early postharvest needle abscission, attributable possibly to earlier harvest dates, reduced cold acclimation periods, and longer shipping

Received for publication 16 Feb. 2012. Accepted for publication 24 Apr. 2012.

This study was funded by NSERC PGS-D, NSERC$\mathrm{CRD}$, and the Christmas Tree Council of Nova Scotia.

We thank the Nova Scotia Department of Natural Resources for use of their Tree Breeding Center in Debert for sample collection. We thank Drs. Andrew Schofield and Allison Hayward for internal revision of the manuscript.

${ }^{1}$ To whom reprint requests should be addressed; e-mail rlada@nsac.ca. distances (Chastagner and Riley, 2003; MacDonald and Lada, 2008). As a result, there has been more interest in understanding the physiology of needle abscission in postharvest balsam fir.

Although several factors have been considered, the role of ethylene has contributed most to our understanding of postharvest needle abscission in balsam fir. Endogenous ethylene evolution reaches detectable limits $(0.1 \mathrm{ppm}$ with ethylene analyzer) 1 week after harvest and then peaks at $\approx 15 \mu \mathrm{L} \cdot \mathrm{g}^{-1} \cdot \mathrm{h}^{-1}$ before abscission occurs (MacDonald et al., $2010,2011 b$ ). If a branch is instead exposed to exogenous ethylene, then abscission occurs $30 \%$ to $70 \%$ earlier than a control and is strongly dependent on the concentration of ethylene (MacDonald et al., 2010, 2011a). The use of an ethylene synthesis or action inhibitor such as aminoethoxyvinylglycine or 1-methylcyclopropene negates the effect of ethylene and doubles the time required for abscission (MacDonald et al., 2010). Endogenous ethylene accumulation or exposure to exogenous ethylene subsequently increases cellulase activity in needle tissue by $\approx 10$-fold, weakening the cell walls and promoting needle abscission (MacDonald, 2010, MacDonald et al., 2011a).

Although a portion of the abscission pathway is understood, the trigger for ethylene evolution is still not known. Initially, it was thought that mechanical wounding from harvest and shipping would trigger ethylene, as observed in other species (O'Donnell et al., 1996). However, the considerable 1 -week lag time between balsam fir harvest and ethylene evolution observed by MacDonald et al. (2010, 2011b) has caused doubt on the role of mechanical stress-induced abscission in postharvest Christmas trees. A second theory is that postharvest water deficit induces ethylene evolution and abscission, which has also been demonstrated in several other species (Morgan et al., 1990; Taylor and Whitelaw, 2001). There is some evidence to suggest that postharvest balsam fir branches are experiencing water deficit, because xylem pressure potential (XPP) in balsam fir decreases after harvest and is negatively correlated with needle retention (MacDonald, 2010), but these studies did not directly explore the link between water status and ethylene evolution. If decreased water status is the cause, then minimizing transpiration (thus maintaining plant water status) by manipulating relative humidity or temperature should reduce or delay ethylene evolution and needle abscission in balsam fir. Thus, the objectives of this study were to 1) determine the effects of temperature and humidity, independently, on ethylene evolution and needle abscission in balsam fir; 2) to determine if temperature or humidity could offset the effect of ethylene on needle abscission; and 3) to link VPD to needle abscission.

\section{Materials and Methods}

Sample collection. A total of 48 branches were collected from a 14-year-old (at the time of experiment) balsam fir orchard at the Tree Breeding Center, Department of Natural Resources, Debert, Nova Scotia, Canada (lat. $45^{\circ} 25^{\prime} \mathrm{N}$, long. $63^{\circ} 28^{\prime} \mathrm{W}$ ). Each branch served as a sample and was cut from 2-year growth at $1.5 \mathrm{~m}$ aboveground. Samples were immediately placed in a container with distilled water for transport to a growth chamber. Once in a growth chamber, branches were given a fresh cut $2.5 \mathrm{~cm}$ above the previous cut (while submerged in water to reduce risk of cavitation), weighed, and then placed in a $250-\mathrm{mL}$ flask filled with $200 \mathrm{~mL}$ of distilled water. The neck of each flask was plugged with cotton wool to reduce direct water evaporation and provide added stability to a branch. Afterward, the entire apparatus was weighed, which allowed for quantification of needle loss and water use throughout the experiment without disturbance to the branches. To monitor ethylene concentrations, each apparatus was then placed in an ethylene incubation chamber (EIC) housed within the 
growth chamber. A detailed description of ethylene incubation chamber construction is provided in MacDonald et al. (2010, 2011b).

Experimental design. Two similar experiments were conducted to investigate the effect of humidity and temperature on needle abscission. The first experiment was a $2 \times 3$ factorial design with four replicates, in which a balsam fir branch served as a replicate. The first factor was ethylene concentration ( 0 or $1000 \mathrm{ppm}$ ), which was selected based on the results of MacDonald et al. (2010). Each branch was placed in an EIC (within a growth chamber) and exposed to either $0 \mathrm{ppm}$ or 1000 ppm exogenous ethylene. After $24 \mathrm{~h}$, each EIC was opened for branch inspection, which allowed exogenous levels of ethylene to drop to $0 \mathrm{ppm}$. Then branches were placed into an EIC and exposed to respective ethylene concentrations again. This process continued until complete abscission occurred. The second factor was humidity $(30 \%, 60 \%$, or $90 \%$ ). Humidity was maintained using misting fans with controlled water flow in the growth chamber and never changed by more than $1 \%$ of the assigned value (measured by two independent sensors inside and outside the ethylene incubation chamber). The EIC was kept at an average temperature of $19.7{ }^{\circ} \mathrm{C}$ with a light intensity of $80 \mu \mathrm{mol} \cdot \mathrm{m}^{-2} \cdot \mathrm{s}^{-1}$ supplied by incandescent and fluorescent lights. The second experiment had a similar experimental design, but the second factor was temperature $(5,15$, or $25{ }^{\circ} \mathrm{C}$ ). During the second experiment, humidity in each chamber was maintained at $60 \%$ in all treatments. As indicated previously, temperature and humidity were monitored inside and outside.

In each experiment, branches were monitored until complete needle abscission occurred. Response variables were needle retention duration (NRD), average water use (AWU), XPP, relative water content (RWC), day of peak ethylene evolution (DPE), and peak ethylene evolution rate. In addition, VPD was calculated for growth chamber conditions in each experiment.

Needle retention duration. The primary measurement of abscission was NRD, which was initially defined as the number of days required for complete needle abscission. Previous experiments determined that the mass of needles on a 2-year-old branch accounts for $\approx 50 \%$ of the total fresh weight (MacDonald, 2010; MacDonald and Lada, 2008; MacDonald et al., 2010). Thus, NRD was quantified as the length of time (days) to lose $50 \%$ of a branch's initial fresh weight through abscission.

Water use and status. The primary indicator for water loss was AWU $\left(\mathrm{mL} \cdot \mathrm{g}^{-1} \cdot \mathrm{d}^{-1}\right)$ and determined gravimetrically. Because each flask was sealed around a standing branch, any change in mass should be the result of either transpiration or needle loss. Each flask with branch was weighed daily, where the measurements were adjusted to account for needle loss that may have occurred overnight. AWU was calculated as:

$$
\frac{\sum\left(\left(M_{0}-M_{i}\right)-M_{n}\right)}{M_{i} \bullet N R D}
$$

where $M_{0}$ is the initial fresh weight of the flask and branch, $M_{\mathrm{i}}$ is the fresh weight on each day, and $M_{\mathrm{n}}$ is the mass of needles lost on each day.

Response variables XPP and RWC were used to indicate water status in balsam fir. Xylem pressure potential of branches was measured using a Plant Moisture System Pressure Bomb (PMS Instrument Co., Corvallis, OR). A clipping from the primary branch was cut on the day of complete needle shed and was mounted upside down inside a pressure chamber and pressure was increased gradually at $0.01 \mathrm{MPa}$ per minute until the water droplets appeared on the cut surface. The pressure required to release a water droplet was recorded. Relative water content was measured on the day of complete needle shed. Approximately $0.1 \mathrm{~g}$ of needles were weighed $\left(\mathrm{M}_{\mathrm{f}}\right)$ and then placed in deionized water to reach full turgidity. After $24 \mathrm{~h}$, the needles were removed from water, surface moisture was removed by dabbing with tissue paper, and needles were weighed $\left(\mathrm{M}_{\mathrm{t}}\right)$. The needles were then dried at $90{ }^{\circ} \mathrm{C}$ for $24 \mathrm{~h}$ and then weighed again $\left(\mathrm{M}_{\mathrm{d}}\right)$. The following calculation was used for RWC:

$$
R W C=\frac{M_{f}-M_{d}}{M_{t}-M_{d}} x 100
$$

Ethylene evolution. Ethylene evolution was determined by transferring each branch to a separate EIC for $3 \mathrm{~h}$ to allow ethylene to increase to a detectable concentration. The EIC remained in the growth chamber and environmental conditions were monitored within EIC to ensure the same temperature and humidity as the growth chamber. Ethylene concentration was measured with a portable ethylene analyzer (Levitt-Safety, Moncton, New Brunswick, Canada) with a sensitivity of $0.1 \mathrm{ppm}$ as described in MacDonald et al. (2010, 2011a). Ethylene
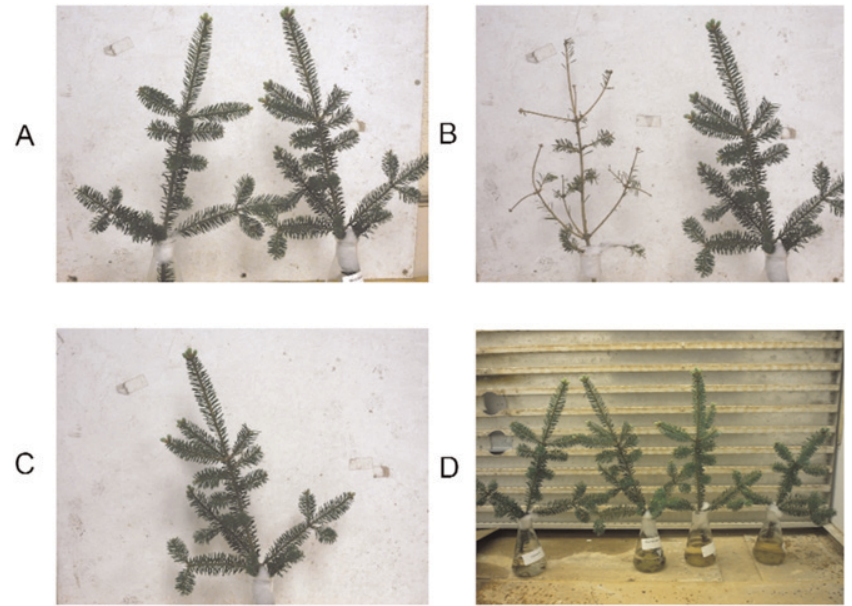

Fig. 1. Comparison of branches stored at (A) 30\% (left) and 90\% (right) humidity on Day 1; (B) $30 \%$ (left) and $90 \%$ (right) humidity on Day 30; and (C) $90 \%$ humidity on Day 60 in the absence of exogenous ethylene. (D) All replications stored at $90 \%$ humidity in the absence of exogenous ethylene are still vibrant and green at Day 90. following equation:

Ethylene evolution $=\frac{\text { Concentration } \times 80 L}{3 h \times \text { Mass }}$

where ethylene evolution is reported in $\mu \mathrm{L} \cdot \mathrm{g}^{-1} \cdot \mathrm{h}^{-1}$, concentration is $\mu \mathrm{L} \cdot \mathrm{L}^{-1}$, and mass is the initial fresh weight $(\mathrm{g})$ of a branch. Ethylene evolution was measured each day; DPE represents the day ethylene evolution was highest.

Vapor pressure deficit. Vapor pressure deficit, which measures the difference between saturated vapor pressure and ambient vapor pressure, is one of the primary factors governing transpiration (Jolliet and Bailey, 1992). VPD is dependent on temperature and humidity and was calculated for each treatment based on equations provided by Monteith and Unsworth (1990):

$$
\begin{aligned}
V P D & =\frac{\left(P_{\text {sat }}\right)(100-R H)}{100} \\
P_{\text {sat }} & =610.7 \times 10^{7.5 T /(237.3+T)}
\end{aligned}
$$

where VPD represents vapor pressure deficit $(\mathrm{Pa}), \mathrm{P}_{\text {sat }}$ represents saturation vapor pressure $(\mathrm{Pa}), \mathrm{RH}$ represents relative humidity $(\%)$, and $\mathrm{T}$ represents temperature $(\mathrm{K})$. Based on this equation, the first experiment had an average daily temperature of $19.7{ }^{\circ} \mathrm{C}$ and treatments of $30 \%, 60 \%$, or $90 \%$ humidity, which corresponded with VPDs of 1.59, 0.91, or $0.23 \mathrm{kPa}$. The second experiment had an average humidity of $60 \%$ and treatments of 5 , 15 , or $25^{\circ} \mathrm{C}$, which corresponded with VPDs of $0.35,0.68$, or $1.26 \mathrm{kPa}$.

Statistical analysis. Data were submitted to an analysis of variance using SAS 9.1 (SAS Institute, Cary, NC) to determine main and interaction effects significant at $\alpha=0.05$. Assumptions of normality, homogeneity, and independence were confirmed. Significant effects were separated using least squares means. Measurements of NRD, XPP, and AWU for each experiment were submitted to linear or non-linear regression analysis to 
determine potential relationships. In addition, non-linear regression analysis was used to determine the relationship between NRD and VPD.

\section{Results}

Effect of humidity on needle abscission. There was a significant $(P<0.001)$ interaction between ethylene concentration and humidity for both NRD and DPE. Humidity had no effect on needle retention in the presence of 1000 ppm ethylene. However, the highest humidity $(90 \%)$ favored needle retention in the absence of ethylene exposure (Fig. 1). A 60\% humidity increased NRD and DPE by $\approx 10 \%$ when compared with $30 \%$ humidity. However, 90\% humidity increased NRD and DPE by more than fivefold when compared with $30 \%$ humidity (Table 1). Neither ethylene concentration nor humidity had any significant $(P>0.05)$ effect on the peak endogenous ethylene evolution rate.

AWU was only affected by humidity. Exposure to $90 \%$ humidity (as opposed to $30 \%$ humidity) resulted in a $50 \%$ decrease in AWU in the presence of ethylene and a $67 \%$ decrease in AWU in the absence of ethylene (Table 2). Under 0 ppm exogenous ethylene, XPP was generally lower at low humidity, whereas humidity has no significant effect on XPP in 1000 ppm treatments. XPP was lower in the presence of exogenous ethylene regardless of humidity. XPP was highest in the absence of ethylene when exposed to $90 \%$ humidity (Table 2 ). RWC followed a similar pattern as XPP. In the absence of ethylene, RWC was maintained at $86.7 \%$ when exposed to $90 \%$ humidity but decreased by $34.1 \%$ when exposed to $30 \%$ humidity. There were no significant differences in RWC in the presence of exogenous ethylene (Table 2).

Effect of temperature on needle abscission. NRD and DPE were significantly affected by both temperature $(P<0.001)$ and ethylene $(P<0.001)$ regimes. Continuous exposure to exogenous ethylene reduced NRD by $47 \%$ to $65 \%$, depending on the temperature regime (Table 3 ). However, NRD was significantly higher at $5{ }^{\circ} \mathrm{C}$ in the presence or absence of ethylene (Table 3; Fig. 2).

The rate of endogenous ethylene evolution was significantly $(P<0.001)$ affected by temperature alone (Table 3 ). There was no difference in ethylene evolution at 5 and $15^{\circ} \mathrm{C}$, which had a combined average evolution rate of $5.2 \mu \mathrm{L} \cdot \mathrm{g}^{-1} \cdot \mathrm{h}^{-1}$. However, there was a $51 \%$ increase in ethylene evolution at $25{ }^{\circ} \mathrm{C}$, resulting in a rate of $7.7 \mu \mathrm{L} \cdot \mathrm{g}^{-1} \cdot \mathrm{h}^{-1}$ when compared with $5{ }^{\circ} \mathrm{C}$. Exogenous ethylene did not influence the endogenous ethylene evolution rate.

AWU, XPP, and RWC were each significantly $(P<0.001)$ influenced by temperature alone. In the absence of ethylene, AWU was $40 \%$ lower, XPP was $124 \%$ higher, and RWC was $17.4 \%$ higher at $5{ }^{\circ} \mathrm{C}$ than $25^{\circ} \mathrm{C}$. In the presence of ethylene, AWU was 51\% lower, XPP was $76 \%$ higher, and RWC was $21 \%$ higher at $5{ }^{\circ} \mathrm{C}$ than $25^{\circ} \mathrm{C}$ (Table 4).
Table 1. Effect of exogenous ethylene and relative humidity on needle retention duration (NRD), days until peak ethylene evolution (DPE), and peak ethylene evolution rates in root-detached balsam fir branches while temperature was maintained at $19.7^{\circ} \mathrm{C} .{ }^{\mathrm{z}}$

\begin{tabular}{|c|c|c|c|c|c|c|c|c|c|c|c|}
\hline \multirow{2}{*}{$\begin{array}{l}\text { Ethylene } \\
\text { (ppm) }\end{array}$} & \multirow{2}{*}{$\begin{array}{c}\text { Humidity } \\
(\%)\end{array}$} & \multirow{2}{*}{$\begin{array}{c}\begin{array}{r}\text { VPD } \\
(\mathrm{kPa})\end{array} \\
1.59\end{array}$} & \multicolumn{3}{|c|}{ NRD (days) } & \multicolumn{3}{|c|}{ DPE (days) } & \multicolumn{3}{|c|}{$\begin{array}{c}\mathrm{C}_{2} \mathrm{H}_{4} \text { evolution } \\
\left(\mu \mathrm{L} \cdot \mathrm{g}^{-1} \cdot \mathrm{d}^{-1}\right)\end{array}$} \\
\hline & & & 28.5 & \pm & $1.0 \mathrm{c}^{\mathrm{y}}$ & 27.0 & \pm & $0.9 \mathrm{c}$ & 7.5 & \pm & $0.6 \mathrm{a}$ \\
\hline & 60 & 0.91 & 32.3 & \pm & $1.1 \mathrm{~b}$ & 30.5 & \pm & $1.0 \mathrm{~b}$ & 6.4 & \pm & $1.0 \mathrm{a}$ \\
\hline & 90 & 0.23 & 149.8 & \pm & $2.1 \mathrm{a}$ & 145.8 & \pm & $3.1 \mathrm{a}$ & 6.1 & \pm & $0.5 \mathrm{a}$ \\
\hline \multirow[t]{3}{*}{1000} & 30 & 1.59 & 11.8 & \pm & $0.9 \mathrm{~d}$ & 10.3 & \pm & $0.6 \mathrm{~d}$ & 5.8 & \pm & $0.7 \mathrm{a}$ \\
\hline & 60 & 0.91 & 12.0 & \pm & $0.4 \mathrm{~d}$ & 10.3 & \pm & $0.3 \mathrm{~d}$ & 5.4 & \pm & $0.2 \mathrm{a}$ \\
\hline & 90 & 0.23 & 13.8 & \pm & $0.5 \mathrm{~d}$ & 12.3 & \pm & $0.8 \mathrm{~d}$ & 7.1 & \pm & $0.5 \mathrm{a}$ \\
\hline \multicolumn{3}{|c|}{$P$ "ethylene" } & \multicolumn{3}{|c|}{$<0.001$} & \multicolumn{3}{|c|}{$<0.001$} & \multicolumn{3}{|c|}{0.272} \\
\hline \multicolumn{3}{|c|}{$P$ "humidity" } & \multicolumn{3}{|c|}{$<0.001$} & \multicolumn{3}{|c|}{$<0.001$} & \multicolumn{3}{|c|}{0.451} \\
\hline \multicolumn{3}{|c|}{$P$ "ethylene $\times$ humidity" } & \multicolumn{3}{|c|}{$<0.001$} & \multicolumn{3}{|c|}{$<0.001$} & \multicolumn{3}{|c|}{0.111} \\
\hline
\end{tabular}

${ }^{\mathrm{z}}$ Treatment means \pm SE were calculated from four replicates.

${ }^{y}$ Any two means within a column not followed by the same letter are significant at $P \leq 0.05$ as determined by least squares means separation.

Table 2. Effect of exogenous ethylene and relative humidity on average water use (AWU), xylem pressure potential (XPP), and relative water content (RWC) in root-detached balsam fir branches while temperature was maintained at $19.7^{\circ} \mathrm{C} .{ }^{\mathrm{z}}$

\begin{tabular}{|c|c|c|c|c|c|c|c|c|c|c|}
\hline $\begin{array}{l}\text { Ethylene } \\
\text { (ppm) }\end{array}$ & $\begin{array}{c}\text { Humidity } \\
(\%)\end{array}$ & $\begin{array}{l}\text { VPD } \\
(\mathrm{kPa})\end{array}$ & \multicolumn{3}{|c|}{ AWU $\left(\mathrm{mL} \cdot \mathrm{g}^{-1} \cdot \mathrm{d}^{-1}\right)$} & \multicolumn{2}{|c|}{$\mathrm{XPP}^{\mathrm{y}}(\mathrm{MPa})$} & \multicolumn{3}{|c|}{$\mathrm{RWC}^{\mathrm{y}}(\%)$} \\
\hline \multirow[t]{3}{*}{0} & 30 & 1.59 & 0.061 & \pm & $0.003 \mathrm{a}^{\mathrm{x}}$ & $-0.73 \quad \pm$ & $0.09 \mathrm{a}$ & 52.6 & \pm & $5.3 \mathrm{c}$ \\
\hline & 60 & 0.91 & 0.038 & \pm & $0.005 \mathrm{~b}$ & -0.40 & $0.05 \mathrm{ab}$ & 69.8 & \pm & $3.3 \mathrm{~b}$ \\
\hline & 90 & 0.23 & 0.021 & \pm & $0.001 \mathrm{c}$ & -0.09 & $0.02 \mathrm{~d}$ & 86.7 & \pm & $1.1 \mathrm{a}$ \\
\hline \multirow[t]{3}{*}{1000} & 30 & 1.59 & 0.058 & \pm & $0.002 \mathrm{a}$ & -0.94 & $0.02 \mathrm{a}$ & 39.7 & \pm & $1.4 \mathrm{~d}$ \\
\hline & 60 & 0.91 & 0.041 & \pm & $0.002 \mathrm{~b}$ & -0.84 & $0.06 \mathrm{~b}$ & 47.1 & \pm & $2.0 \mathrm{~cd}$ \\
\hline & 90 & 0.23 & 0.029 & \pm & $0.007 \mathrm{bc}$ & -0.81 & $0.04 \mathrm{c}$ & 47.6 & \pm & $2.1 \mathrm{~cd}$ \\
\hline \multicolumn{3}{|c|}{$P$ "ethylene" } & \multicolumn{3}{|c|}{0.469} & \multicolumn{2}{|c|}{0.047} & \multicolumn{3}{|c|}{$<0.001$} \\
\hline \multicolumn{3}{|c|}{$P$ "humidity" } & \multicolumn{3}{|c|}{$<0.001$} & \multicolumn{2}{|c|}{$<0.001$} & \multicolumn{3}{|c|}{$<0.001$} \\
\hline \multicolumn{3}{|c|}{$P$ "ethylene $\times$ humidity" } & \multicolumn{3}{|c|}{0.427} & \multicolumn{2}{|c|}{0.001} & \multicolumn{3}{|c|}{0.001} \\
\hline
\end{tabular}

${ }^{\mathrm{z} T r e a t m e n t}$ means $\pm \mathrm{SE}$ were calculated from four replicates.

${ }^{\mathrm{y}}$ Measurements taken on last day of needle abscission.

${ }^{x}$ Any two means within a column not followed by the same letter are significant at $P \leq 0.05$ as determined by least squares means separation.

Table 3. Effect of exogenous ethylene and temperature on needle retention duration (NRD), days until peak ethylene evolution (DPE), and peak ethylene evolution rates in root-detached balsam fir branches while humidity was maintained at $60 \%$. $^{\mathrm{z}}$

\begin{tabular}{|c|c|c|c|c|c|c|c|c|c|c|c|}
\hline \multirow{2}{*}{$\begin{array}{l}\text { Ethylene } \\
\text { (ppm) } \\
0\end{array}$} & \multirow{2}{*}{$\begin{array}{c}\text { Temp } \\
\left({ }^{\circ} \mathrm{C}\right)\end{array}$} & \multirow{2}{*}{$\begin{array}{r}\begin{array}{r}\text { VPD } \\
(\mathrm{kPa})\end{array} \\
0.35\end{array}$} & \multicolumn{3}{|c|}{ NRD (days) } & \multicolumn{3}{|c|}{ DPE (days) } & \multicolumn{3}{|c|}{$\begin{array}{c}\mathrm{C}_{2} \mathrm{H}_{4} \text { evolution } \\
\left(\mu \mathrm{L} \cdot \mathrm{g}^{-1} \cdot \mathrm{d}^{-1}\right)\end{array}$} \\
\hline & & & 65.0 & \pm & $2.2 \mathrm{a}^{\mathrm{y}}$ & 61.5 & \pm & $1.9 \mathrm{a}$ & 4.9 & \pm & $0.3 \mathrm{~b}$ \\
\hline & 15 & 0.68 & 37.5 & \pm & $1.2 \mathrm{~b}$ & 34.5 & \pm & $1.0 \mathrm{~b}$ & 4.7 & \pm & $0.3 \mathrm{~b}$ \\
\hline & 25 & 1.26 & 29.5 & \pm & $1.0 \mathrm{c}$ & 27.8 & \pm & $1.5 \mathrm{c}$ & 7.4 & \pm & $0.5 \mathrm{a}$ \\
\hline \multirow[t]{3}{*}{1000} & 5 & 0.35 & 20.8 & \pm & $0.6 \mathrm{~d}$ & 18.0 & \pm & $0.6 \mathrm{~d}$ & 5.3 & \pm & $0.5 \mathrm{~b}$ \\
\hline & 15 & 0.68 & 13.3 & \pm & $0.6 \mathrm{e}$ & 11.5 & \pm & $0.3 \mathrm{e}$ & 5.8 & \pm & $0.9 \mathrm{~b}$ \\
\hline & 25 & 1.26 & 11.0 & \pm & $0.9 \mathrm{e}$ & 9.5 & \pm & $1.0 \mathrm{e}$ & 8.0 & \pm & $0.4 \mathrm{a}$ \\
\hline \multicolumn{3}{|c|}{$P$ "ethylene" } & \multicolumn{3}{|c|}{$<0.001$} & \multicolumn{3}{|c|}{$<0.001$} & \multicolumn{3}{|c|}{0.127} \\
\hline \multicolumn{3}{|c|}{$P$ "temp" } & \multicolumn{3}{|c|}{$<0.001$} & \multicolumn{3}{|c|}{$<0.001$} & \multicolumn{3}{|c|}{$<0.001$} \\
\hline \multicolumn{3}{|c|}{$P$ "ethylene $\times$ temp" } & \multicolumn{3}{|c|}{$<0.001$} & \multicolumn{3}{|c|}{$<0.001$} & \multicolumn{3}{|c|}{0.802} \\
\hline
\end{tabular}

zTreatment means \pm SE were calculated from four replicates.

${ }^{y}$ Any two means within a column not followed by the same letter are significant at $P \leq 0.05$ as determined by least squares means separation.

Relationships among vapor pressure deficit, water use, and needle abscission. In both experiments, exogenous ethylene significantly reduced NRD. However, in the absence of exogenous ethylene, several significant $(P<0.001$ for all $)$ relationships were found. There was a strong $\left(R^{2}=0.71\right)$ positive linear relationship between VPD and AWU and a strong $\left(R^{2}=0.68\right)$ negative exponential relationship between VPD and XPP (Fig. 3). That is, when VPD is relatively high, AWU tends to be high, whereas XPP becomes more negative. In addition, VPD has a nearly perfect $\left(R^{2}=0.99\right)$ negative exponential relationship with NRD (Fig. 3). Consequently, both AWU and XPP

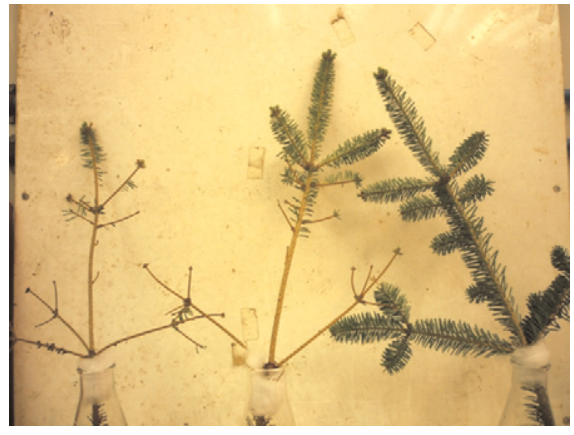

Fig. 2. Comparison of branches stored at $25{ }^{\circ} \mathrm{C}$ (left), $15^{\circ} \mathrm{C}$ (middle), and $5{ }^{\circ} \mathrm{C}$ (right) on Day 35 in the absence of exogenous ethylene. 
Table 4. Effect of exogenous ethylene and temperature on average water use (AWU), xylem pressure potential (XPP), and relative water content (RWC) in root-detached balsam fir branches while humidity was maintained at $60 \%$. $^{\mathrm{z}}$

\begin{tabular}{|c|c|c|c|c|c|c|c|c|c|c|c|}
\hline $\begin{array}{l}\text { Ethylene } \\
\text { (ppm) }\end{array}$ & $\begin{array}{l}\text { Temp } \\
\left({ }^{\circ} \mathrm{C}\right)\end{array}$ & $\begin{array}{l}\mathrm{VPD} \\
(\mathrm{kPa})\end{array}$ & \multicolumn{3}{|c|}{$\mathrm{AWU}\left(\mathrm{mL} \cdot \mathrm{g}^{-1} \cdot \mathrm{d}^{-1}\right)$} & \multicolumn{3}{|c|}{$\mathrm{XPP}^{\mathrm{y}}(\mathrm{MPa})$} & \multicolumn{3}{|c|}{$\mathrm{RWC}^{\mathrm{y}}(\%)$} \\
\hline \multirow[t]{3}{*}{0} & 5 & 1.59 & 0.035 & \pm & $0.004 \mathrm{c}^{\mathrm{x}}$ & -0.34 & \pm & $0.03 \mathrm{c}$ & 69.0 & \pm & $2.0 \mathrm{a}$ \\
\hline & 15 & 0.91 & 0.045 & \pm & $0.002 \mathrm{~b}$ & -0.64 & \pm & $0.06 \mathrm{~b}$ & 57.2 & \pm & $3.3 \mathrm{~b}$ \\
\hline & 25 & 0.23 & 0.058 & \pm & $0.004 \mathrm{a}$ & -0.76 & \pm & $0.06 \mathrm{ab}$ & 51.6 & \pm & $2.5 \mathrm{c}$ \\
\hline \multirow[t]{3}{*}{1000} & 5 & 1.59 & 0.032 & \pm & $0.003 \mathrm{c}$ & -0.51 & \pm & $0.07 \mathrm{~b}$ & 64.5 & \pm & $3.8 \mathrm{a}$ \\
\hline & 15 & 0.91 & 0.042 & \pm & $0.002 \mathrm{bc}$ & -0.60 & \pm & $0.05 \mathrm{~b}$ & 60.5 & \pm & $3.6 \mathrm{ab}$ \\
\hline & 25 & 0.23 & 0.065 & \pm & $0.001 \mathrm{a}$ & -0.90 & \pm & $0.07 \mathrm{a}$ & 43.5 & \pm & $3.5 \mathrm{~d}$ \\
\hline \multicolumn{3}{|c|}{$P$ "ethylene" } & \multicolumn{3}{|c|}{0.852} & \multicolumn{3}{|c|}{0.066} & \multicolumn{3}{|c|}{0.250} \\
\hline \multicolumn{3}{|c|}{$P$ "temp" } & \multicolumn{3}{|c|}{$<0.001$} & \multicolumn{3}{|c|}{$<0.001$} & \multicolumn{3}{|c|}{$<0.001$} \\
\hline \multicolumn{3}{|c|}{$P$ "ethylene $\times$ temp" } & \multicolumn{3}{|c|}{0.196} & \multicolumn{3}{|c|}{0.171} & \multicolumn{3}{|c|}{0.211} \\
\hline
\end{tabular}

Treatment means \pm SE were calculated from four replicates.

${ }^{\mathrm{y}}$ Measurements taken on last day of needle abscission.

${ }^{\mathrm{x}}$ Any two means within a column not followed by the same letter are significant at $P \leq 0.05$ as determined by least squares means separation.
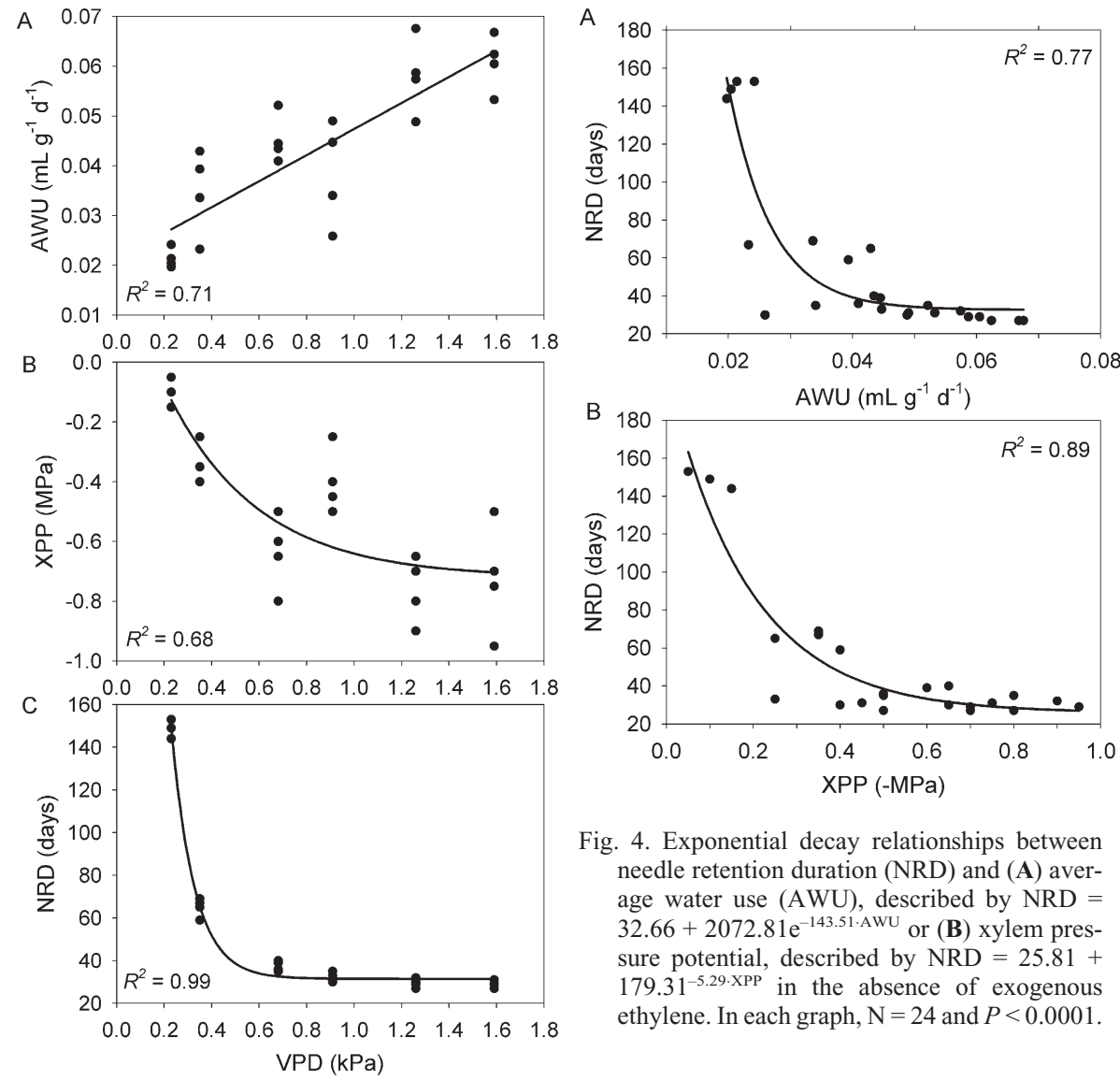

Fig. 3. Relationships between vapor pressure deficit (VPD) and (A) average water use (AWU)- linear descrisbed by AWU $=0.021+0.026 \cdot V P D ;(B)$ xylem pressure potential (XPP) - exponential decay described by XPP $=-0.72+1.08 \mathrm{e}^{-2.60 \cdot \mathrm{VPD}}$; or (C) needle retention duration (NRD) exponential decay described by $\mathrm{NRD}=31.51+$ $1277.74 \mathrm{e}^{-10.35 \cdot \mathrm{VPD}}$ in the absence of exogenous ethylene. In each graph, $\mathrm{N}=24$ and $P<0.0001$.

are strongly $\left(R^{2}=0.77\right.$ and 0.89 , respectively) associated with NRD in the absence of exogenous ethylene (Fig. 4). Finally, RWC had significant relationships with both VPD and NRD but neither as strong as the aforementioned relationships (data not shown).
1985); thus, it is logical to suggest that XPP may act as a biophysical trigger for ethylene synthesis. Our results tend to support this hypothesis. When water loss was limited in the absence of exogenous ethylene, NRD significantly increased. Branches stored at $5{ }^{\circ} \mathrm{C}$ and $60 \%$ humidity had a $120 \%$ increase in NRD, whereas NRD increased more than fivefold at $90 \%$ humidity and $19.7{ }^{\circ} \mathrm{C}$. Mitcham-Butler et al. (1988) previously reported storage at lower temperature as an effective method of delaying abscission in fraser fir [Abies fraseri (Pursh) Poir.], but our study is the first known instance of using high humidity to delay needle abscission in conifers. In addition, low temperatures and high humidity significantly delayed the evolution of ethylene and maintained higher XPP, which suggests a potential role for water status in postharvest abscission.

There remain some problems in definitively identifying XPP as the trigger for ethylene synthesis and needle abscission in conifers. First, if we know that limiting water loss through humidity or temperature decreases abscission, we would expect antitranspirant compounds to have a similar effect However, in most cases, there was no improvement noted (Chastagner and Riley, 1991) or there was a reduction in transpiration, but not enough to be of any practical significance to delay abscission (Davis and Fretz, 1972; Duck et al., 2003). Second, branches stored at $90 \%$ humidity still eventually lost needles despite having a final XPP of $-0.1 \mathrm{MPa}$ and continued water uptake throughout the experiment. Finally, XPP was not nearly as low as the expected damage threshold. The damage threshold is the moisture content at which tree tissue experiences irreversible damage such as dryness, brittleness, discoloration, and abscission (Hinesley and Snelling, 1995; Montano and Proebsting, 1985). The lowest water potential observed in balsam fir during complete abscission was only $-1.0 \mathrm{MPa}$, which is considerably higher than damage threshold water potentials of $-3.0 \mathrm{MPa}$ to $-4.0 \mathrm{MPa}$ observed in closely related species such as nordmann fir [Abies nordmanniana (Steven) Spach] and fraser fir (Chastagner and Riley, 2003; Mitcham-Butler et al., 1988). This final point was also observed by Heiligmann and Brown (2005), who monitored five species of Christmas trees for postharvest needle and moisture retention and found that no tree experienced XPP as low as the damage threshold. Heiligmann and Brown (2005) speculated that damage thresholds may vary between individual trees; thus, some sample tissues may become damaged at much higher moisture contents. However, in that study, average XPP was recorded in the range of -1.5 to $-2.5 \mathrm{MPa}$ during abscission; in our study, average XPP was recorded in the range of -0.3 to $-0.7 \mathrm{MPa}$, which is much farther from the damage threshold and less likely to be the result of individual variation in trees. It is also noteworthy that the study from Heiligmann and Brown (2005) used branches cut from a full tree in water as opposed to individual branches placed in water. 
It must be considered that another variable, although perhaps linked with water status, may be acting as the trigger for abscission. We speculate that changes in postharvest cytokinin concentration may be a factor. $\mathrm{Cy}$ tokinins are produced, in part, by meristematic root tissue and then transported to shoot and leaves (Bano et al., 1993). Generally the concentration of cytokinins is relatively high but will quickly decrease during periods of water stress (Bano et al., 1993) such as declining XPP observed in balsam fir, possibly contributing to abscission. In contrast, exogenous application of certain cytokinins can delay or negate abscission in some species (Meir et al., 2007). Postharvest balsam fir trees are separated from roots, perhaps reducing cytokinin translocation and synthesis as well as triggering cytokinin degradation. Any method to reduce transpiration such as high humidity or low temperature could slow the degradation of existing cytokinins and delay abscission. Still, the concentration of cytokinins will eventually decrease without roots to synthesize new cytokinins, which may explain why abscission occurred even when XPP was maintained at $-0.10 \mathrm{MPa}$.

Previous studies with exogenous ethyleneinduced abscission reveal that low XPP may be a consequence of ethylene evolution as opposed to a trigger. Continuous exposure to exogenous ethylene induced rapid abscission and a significantly lower XPP than a control, although daily water use had not stabilized (MacDonald, 2010). It has been suggested that ethylene causes stomatal dysfunction in some species, resulting in increased stomatal conductance and transpiration (Azuma et al., 2003; Merritt et al., 2001; Tanaka et al., 2005). It was speculated that ethylene evolution occurs after harvest and causes some stomatal dysfunction, which may result in abscission attributable to elevated transpiration and limited water uptake, although there remain some problems with this hypothesis. If this is the case, exogenous ethylene should not induce abscission during times of reduced transpiration. However, when water loss (and consequently, transpiration) was successfully mitigated using high humidity or low temperature, exogenous ethylene still induced needle abscission. These results do not necessarily dispute that continuous exposure to ethylene may result in some degree of stomatal dysfunction, because XPP was significantly lower in the presence of ethylene, but stomatal dysfunction is clearly not the major contributor to postharvest needle abscission.
In conclusion, both the $90 \%$ humidity and $5{ }^{\circ} \mathrm{C}$ treatments were effective at delaying abscission in root-detached balsam fir in the absence of ethylene. The $90 \%$ humidity treatment was particularly effective with more than a fivefold improvement in NRD, although neither treatment improved NRD in the presence of exogenous ethylene. In addition, NRD was strongly linked to VPD. These results support the hypothesis that declining water status may be a trigger for ethylene evolution and abscission under normal postharvest conditions. However, water status is unlikely the only trigger because abscission eventually occurred in branches that maintained high XPP and RWC. Although the results may not have practical application once trees are displayed in consumer homes (because maintaining low temperature or high humidity may be unrealistic), there may be a practical application to producers, who may be able to incorporate humidity or temperature control in storage or transport.

\section{Literature Cited}

Azuma, T., T. Hatanaka, N. Uchida, and T. Yasuda. 2003. Enhancement of transpiration by ethylene is responsible for absence of internodal elongation in floating rice at low humidity. J. Plant Physiol. 160:1125-1128.

Bano, A., K. Dorfling, D. Bettin, and H. Hahn. 1993. Abscisic acid and cytokinins as possible root-to-shoot signals in xylem sap of rice plants in drying soil. Aust. J. Plant Physiol. 20:109-115.

Chastagner, G.A. and K. Riley. 1991. Effect of foliar sprays of antitranspirants on the postharvest quality of Douglas-fir Christmas trees. California Christmas Tree Assn. Bul. 143:36-40.

Chastagner, G.A. and K.L. Riley. 2003. Postharvest quality of noble and nordmann fir Christmas trees. HortScience 38:419-421.

Davis, T.S. and T.A. Fretz. 1972. The anti-transpirant effect on harvested Christmas trees. Amer. Christmas Tree J. 16:3-5.

Duck, M.W., B.M. Cregg, F.F. Cardoso, R.T. Fernandez, B.K. Behe, and R.D. Heins. 2003. Can antitranspirants extend the shelf life of live table-top Christmas trees. Acta Hort. 618:153-161.

Heiligmann, R.B. and J.H. Brown. 2005. Postharvest needle retention and moisture characteristics of Canaan fir compared with four other Christmas tree species. North. J. Appl. For. 22:268-274.

Hinesley, L.E. and L.K. Snelling. 1991. Vapor pressure deficit, temperature, and light affect postharvest drying of fraser fir and Eastern white pine. HortScience 26:402-405.

Hinesley, L.E. and L.K. Snelling. 1995. Postharvest drying of Leyland cypress, eastern red cedar, and fraser fir Christmas trees. HortScience 30:1427-1428.
Jolliet, O. and B.J. Bailey. 1992. The effect of climate on tomato transpiration in greenhouses: Measures and models comparison. Agr. For. Meteorol. 58:43-62.

MacDonald, M.T. 2010. Physiological significance of ethylene in needle abscission of root-detached balsam fir (Abies balsamea L.). PhD diss., Université Laval, Quebec, Canada.

MacDonald, M.T. and R.R. Lada. 2008. Cold acclimation can benefit only the clones with poor needle retention duration (NRD) in balsam fir. HortScience 43:1273 (Abstr.).

MacDonald, M.T., R.R. Lada, M. Dorais, and S. Pepin. 2011a. Endogenous and exogenous ethylene induces needle abscission and cellulase activity in postharvest balsam fir (Abies balsamea L.). Trees (Berl.) 25:947-952.

MacDonald, M.T., R.R. Lada, A.I. Martynenko, M. Dorais, S. Pepin, and Y. Desjardins. 2011b. Ethylene exposure duration affects postharvest needle abscission in balsam (Abies balsamea L.). HortScience 46:260-264.

MacDonald, M.T., R.R. Lada, A.I. Martynenko, M. Dorais, S. Pepin, and Y. Desjardins. 2010 Ethylene triggers needle abscission in rootdetached balsam fir. Trees (Berl.) 24:879-886.

Meir, S., S. Salim, Z. Chernov, and S. PhilosophHadas. 2007. Quality improvement of cut flowers and potted plants with postharvest treatments based on various cytokinins and auxins. Acta Hort. 755:143-154.

Merritt, F., A. Kemper, and G. Tallman. 2001. Inhibitors of ethylene synthesis inhibit auxininduced stomatal opening in epidermis detached from leaves of Vicia faba L. Plant Cell Physiol. 42:223-230.

Mitcham-Butler, E.J., L.E. Hinesley, and D.M. Pharr. 1988. Effect of harvest date, storage temperature, and moisture status on postharvest needle retention of fraser fir. J. Environ. Hort. 6:1-4.

Montano, J.M. 1985. Postharvest water relations and needle abscission in cut trees of Douglas-fir (Pseudotsuga menziesii Mirb. Franco). PhD diss., Oregon State University, OR.

Montano, J.M. and W.M. Proebsting. 1985. Effects of drying on cut Douglas fir. J. Amer. Soc. Hort. Sci. 110:751-754.

Monteith, J.L. and M.H. Unsworth. 1990. Principles of environmental physics. 3rd Ed. Academic Press, Burlington, MA.

Morgan, P.W., C. He, J.A. De Greef, and M.P. De Proft. 1990. Does water deficit stress promote ethylene synthesis by intact plants? Plant Physiol. 94:1616-1624.

O’Donnell, P.J., C.M. Calvert, R. Atzorn, C. Wasternack, H.M.O. Leyser, and D.J. Bowles. 1996. Ethylene as a signal mediating the wound response of tomato plants. Science 274:1914 1917.

Tanaka, Y., T. Sano, M. Tamaoki, N. Nakajima, N. Kondo, and S. Hasezawa. 2005. Ethylene inhibits abscisic acid-induced stomatal closure in Arabidopsis. Plant Physiol. 138:2337-2343.

Taylor, J.E. and C.A. Whitelaw. 2001. Signals in abscission. New Phytol. 151:323-339. 